\author{
Marta Ulańska \\ Uniwersytet Łódzki
}

\title{
Mikrotoponimy w systemie identyfikacji wizualnej wybranych lódzkich firm medycznych
}

W pracy dokonana została analiza wybranych elementów sytemu identyfikacji wizualnej na przykładzie łódzkich firm. Obiektem zainteresowań jest funkcjonowanie w tym systemie nazwy firmy - mikrotoponimu, a także związek elementów strukturalno-semantycznych nazwy z jej wizualizacją. Zgromadzony materiał obejmuje blisko 100 nazw łódzkich firm specjalizujących się w branży medycznej. Nazwy zostały zebrane na podstawie wykazu nazw firm zarejestrowanych w Krajowym Rejestrze Sądowym (są to w szczególności spółki) na terenie Łodzi w latach 2001-2002 oraz 2011-2012 ${ }^{1}$.

Mikrotoponimy to nazwy terenowe m.in. nazwy dróg, pól, lasów, łąk, rzek, jezior [por. Kucała, Urbańczyk 1999, 225-226]. H. Górnowicz do mikrotoponimów zalicza nazwy niezamieszkanych obiektów (ulice, place), jak również nazwy pojedynczych drzew, głazów, a nawet cmentarzy [Górnowicz 1998: 14 i n.]. Ze względu na to, iż nazwy firm stały się częścią miejskiego krajobrazu, wyróżniają się na tle innych obiektów i można im przypisać cechy nieożywionego obiektu utworzonego przez człowieka [por. Łobodzińska za Rzetelską-Feleszko 2000: 71], uznaje się je za mikrotoponimy. Takie stanowisko prezentują E. Rzetelska-Feleszko i D. Kopertowska. Rzetelska-Feleszko nazwy firm włącza do toponimów (podobnie jak Cz. Kosyl), zaś Kopertowska określa je mianem mikrotoponimów miejskich. Pojęciem nazewnictwo miejskie posługuje się K. Handke [1998: 283]. Odmienne stanowisko przedstawia E. Breza, który zalicza nazwy firm do obszernej grupy chrematonimów. Na określenie nazw przedsiębiorstw stosuje pojęcia: ergonimy lub instytucjonimy [Breza 1998: 348]².

Materiał wykorzystany w referacie stanowi niewielką część materiału zgromadzonego do pracy doktorskiej. W artykule zaprezentowane zostaną tylko wybrane com.pl/.

${ }^{1}$ Przykłady pochodzą z internetowego Krajowego Rejestru Sądowego, www.krs-online.

${ }^{2}$ Ze względu na liczne polemiki badaczy dotyczące terminologii nazw własnych, a także ograniczoną rozpiętość pracy, problem ten został krótko zasygnalizowany. Więcej rozważań na ten temat znajduje się w rozprawie doktorskiej. 
przykłady, ukazujące w wyrazisty sposób tendencje panujące w nazewnictwie łódzkich przedsiębiorstw na przełomie ostatniej dekady, których znaki graficzne są dostępne zarówno na stronach internetowych, jak i na budynkach siedzib tych przedsiębiorstw.

Pod względem strukturalnym zebrane mikrotoponimy zostały podzielone na dwie podstawowe grupy: nazwy rodzime oraz nazwy obce lub stylizowane na obce. W obrębie nazw rodzimych wyróżniono konstrukcje odantroponimiczne oraz konstrukcje odapelatywne.

Wśród konstrukcji odantroponimicznych wyróżnione zostały nazwy: (a) złożone $\mathrm{z}$ fragmentu imienia i nazwiska lub fragmentu nazwiska wzbogacone o cząstkę morfologiczną, np. MED-MAR - Marcin Jasiński; IKS DENT - Iwona Kral-Szymańska; BEJA- MED - Beata Fortak, Jadwiga Trojanowska-Lipczyk; E DENT - Ewa Zmysłowska-Polakowska; AD DENT - Aneta Praska-Jaros, Dorota Marciniak; WIEDENT - L. Wieteska-Baron, L. Wieteski; (b) utworzone z imienia/imion lub nazwiska/ nazwisk założycieli (współwłaścicieli) firmy oraz części opisowej, np. CENTRUM GINEKOLOGII I POEOŻNICTWA-Suzin, Sieroszewski; WŁODARCZYK I PARTNER-LEKARZE); Gabinet Stomatologiczny Elżbieta Figas-Kubica, Sklep medyczny. Małgorzata Dutkiewicz; Adam Tomaszewski i Partnerzy, Świadczenia Ginekologiczne i Położnicze-Poradnia dla Kobiet; (c) utworzone z fragmentu lub całości nazwiska/ nazwisk (także imion i nazwisk) bez dodatkowej cząstki morfologicznej lub opisowej, np.: KARIMA - Paweł Karmański, Jerzy Mazur); Dąbrowska\&Kurowski.

Do nazw odapelatywnych należą: (a) nazwy równe pojedynczym wyrazom pospolitym, np. GAMETA; KINEZA, (b) złożone nazwy opisowe (złożone z kilku leksemów), np. PRZYCHODNIA DLA ZWIERZAZT; (c) composita chrematonimiczne ${ }^{3}$, które A. Gałkowski traktuje jako zintegrowane konstrukcje, dające się rozłożyć na stosunkowo autonomiczne części, w tym: composita bezłącznikowe, np. TYR MED oraz composita ściagnięte, np. Laserdent, Almed; SANMED; (d) nazwy złożone z firmonimu w formie compositum oraz części opisowej, np. FABRYKA APARATURY ELEKTROMEDYCZNEJ FAMED Łódź.

W zebranym materiale znacznie mniejszą grupę tworzą nazwy obce lub stylizowane na obce. Są to m.in. nazwy równe pojedynczym leksemom obcym, np. REMEDIUM; złożone $\mathrm{z}$ dwóch leksemów, np. BONUS MEDICUS, MEDICA VITAE; złożone z dwóch leksemów połączonych bezpośrednio, np. TęczaNova, VETCOMPLEX; w formie compositum bezłącznikowego, np. PRO ONE. Cieszyć może fakt, że mikrotoponimy te nie stanowią licznego zbioru (a tego typu konstrukcje bywają dla części odbiorców niejasne i niezrozumiałe).

Odnotowano tylko kilka przykładów firmonimów zaliczanych do zbioru nazw mieszanych, będących połączeniem członów rodzimych lub przyswojonych do polszczyzny i obcych (lub stylizowanych na obce). Mogą zawierać cząstkę

${ }^{3}$ Klasyfikacja compositów chrematomicznych przejęta za A. Gałkowskim. Badacz wyróżnia jeszcze trzy grupy, tzw. composita konstrukcyjnie mieszane, composita łacznikowe oraz composita $z$ apostrofem i kropka. W przedstawionej klasyfikacji zostały one pominięte, gdyż w zebranych materiale nie odnaleziono przykładów takich nazw. 
morfologiczną lub quasi-morfologiczną (pozbawioną wartości semantycznych), np. -ex, np. Mobilex (sprzedaż wózków inwalidzkich); -tex, np. TEXPRO (producent nici chirurgicznych); -inter, np. INTERMED (NZOZ);- maks, np. MEDMAKS (NZOZ; spolszczona pisownia cząstki -max); - multi, np. Multi Dent (gabinet stomatologiczny); -ax, np. OMIDAX (utworzona analogicznie do cząstki -ex), rzadziej natomiast zbudowane są z kilku leksemów: TęczaNova, ATELIER ZDROWIA, KAVO POLSKA, MEDISO POLSKA, V!GO Ortho Polska (nazwy firm zagranicznych działających na terenie kraju, o czym informuje zawarty w mikrotoponimach leksem Polska).

Ze względu na wartość semantyczną nazw zebrane przykłady można podzielić na: (a) nazwy kojarzące się branżą, np. GAMETA, PRZYCHODNIA DLA ZWIERZAZT, FABRYKA APARATURY ELEKTROMEDYCZNEJ FAMED Lódź; (b) nazwy niewywołujące skojarzeń (m.in. firmonimy odantroponimiczne, niektóre konstrukcje obce), np. Dabrowska\&Kurowski; PRO ONE, (c) nazwy kontrastujące z działalnością zakładów, np. UNI4MED (branża budowlana) TęczaNova.

Dobra nazwa powinna spełniać kilka kryteriów. Zdaniem specjalistów od namingu (działu marketingu, który zajmuje się kreowaniem nazw, haseł reklamowych, sloganów itp.) powinna być krótka, łatwo zapadająca w pamięć, zrozumiała dla klienta, oryginalna i rozpoznawalna na tle innych. Istotne jest, by przystawała do charakteru działalności firmy oraz wywoływała pozytywne asocjacje u odbiorców. Przy tworzeniu nazwy pod uwagę należy brać jej wymowę oraz pisownię, a także techniczne możliwości przedstawiania, obrazowania mikrotoponimu w systemie identyfikacji wizualnej, czyli m.in. czytelność nazwy w każdym formacie, możliwość przedstawienia jej na szyldach, tablicach, transparentach, fotografiach, w animacjach telewizyjnych [por. Gałkowski za Monachesim 2008: 73].

Na postawie analizy strukturalno-semantycznej mikrotoponimów można zauważyć, że większość z nich nie spełnia co najmniej jednego ze wskazanych kryteriów, np. zwięzłości (FABRYKA APARATURY ELEKTROMEDYCZNEJ FAMED Łódź), przejrzystości (V!GO Ortho Polska) $)^{5}$ czy fortunności (TYR MED).

Większość odnotowanych nazw firmowych, zarówno polskich, jak i obcych, zawiera czytelny element semantyczny, morfem lub wyraz, informujący wprost (np. PRZYCHODNIA DLA ZWIERZĄT) lub pośrednio (np. GAMETA), czym zajmuje się dana firma. Do wyjątków należą nazwy, które nie mają związku z działalnością przedsiębiorstwa lub z nią kontrastują.

Nazwa firmy jest jednym z najważniejszych elementów systemu identyfikacji wizualnej. To pierwszy komunikat o przedsiębiorstwie. Jeśli jest dobrze dobrana może przyczynić się do zwiększenia rozpoznawalności firmy i jej produktów, a także pomóc w budowaniu pozycji firmy na rynku.

\footnotetext{
${ }^{4}$ Przedsiębiorstwo funkcjonuje w branży budowlanej. Nawet angielska postać chrematonimu uniformed nie ma związku z jego działalnością.

${ }^{5}$ Cieszy fakt, że nazwy obce lub stylizowane na obce nie stanowią licznej grupy.
} 
System identyfikacji wizualnej to część tzw. systemu Corporate Identity $(C I)$ - tożsamości przedsiębiorstwa. Termin ten powstał na gruncie amerykańskim w latach $50 .{ }^{6}$ Celem tworzenia systemu jest przede wszystkim odróżnianie się od konkurencji, zdobycie i zwiększanie udziału w rynku, podkreślenie nowych kierunków rozwoju, tworzenie wizerunku i tożsamości organizacji [por. Fleischer 2003: 109]. Proces kształtowania CI jest długotrwały. Działania podejmowane w jego zakresie powinny być zaplanowane, spójne, a także aktualizowane. W przeciwnym razie mogą działać na szkodę firmy [por. Nikodemska-Wołowik, Górski, Wołowik 2004: 58].

$\mathrm{Na}$ CI składają się trzy podstawowe elementy: system wizualny (corporate design) - najistotniejszy z punktu widzenia analizy podjętej w artykule, system zachowań (corporate behaviour), system komunikacji (corporate communication).

Do systemu identyfikacji wizualnej (całościowej identyfikacji), oprócz nazwy, M. Fleischer włącza takie składniki identyfikujące firmę i odróżniające ją od konkurencji, jak: znak graficzny (jego kształt, kolorystyka, rodzaj czcionki), formę typograficzną sloganu, a także wygląd strony internetowej, opakowania (w przypadku firm zajmujących się sprzedażą produktów). Elementy systemu identyfikacji wizualnej mogą być umieszczane m.in. na wizytówkach, drukach firmowych, odzieży roboczej, środkach transportu czy szyldach [por. Fleischer 2003: 128] ${ }^{7}$. Powinny stanowić uporządkowaną, spójną całość, wzajemnie się łączyć i uzupełniać. Użycie nazwy niezbędne jest m.in. w adresach stron internetowych czy adresach poczty elektronicznej [por. Zboralski 2000: 39-40]. Odpowiednio skonstruowana nazwa jest istotnym, o ile nie najważniejszym, elementem kreowania wizerunku przedsiębiorstwa. Jest ona także jednym z głównych składników tzw. brandingu, procesu polegającego na budowaniu świadomości marki przez konstruowanie odpowiedniej nazwy oraz systemu identyfikacji wizualnej, przyczyniającego się do zaistnienia i utrwalenia w umysłach odbiorców danej firmy czy produktu. Nazwa stanowi podstawę, do której dodaje się, dopasowuje pozostałe elementy systemu wizualnego. Obecnie, kiedy powstaje coraz więcej firm, istotne jest, by tworzyć spójny wizerunek przedsiębiorstwa i o niego dbać. Dotyczy to nie tylko światowych koncernów, ale również zakładów funkcjonujących na lokalnym rynku, które muszą sprostać wymaganiom klientów i rosnącej konkurencji.

${ }^{6} \mathrm{Na}$ rodzimym gruncie został utworzony odpowiednik angielskiego CI - Całościowa Identyfikacja. Jego twórcy podkreślaja, że ,zastąpienie słowa corporate wyrażeniem całościowa pozwoliło uniknąć ograniczeń semantycznych występujących w języku angielskim" Termin Całościowa Identyfikacja został stworzony na przełomie lat 80. i 90. XX wieku przez autorów książki Nie tylko logotyp. Wyróżnienie i przynależność w biznesie - A.M. Nikodemską-Wołowik, T.P. Górskiego oraz M. Wołowika.

${ }^{7}$ K. Ragin-Skorecka w publikacji Corporate Identity przedstawia szerszą klasyfikację. W obrębie corporate identity wyróżnia: organizational communication, organizational symbols, organizational culture, behaviour, organizational structure, organization's strategy oraz business identity. Za symbole tzw. visual identity uznaje: name, slogan, color, character of advertisements, workers' outfits, packaging etc. [Ragin-Skorecka 2010: 11-12]. 
Jak już wspomniano, corporate design to jeden z najważniejszych elementów wpływających na proces kreowania wizerunek przedsiębiorstwa. Nazwa firmy, czyli znak językowy, wymaga oprawy wizualnej. Do analizy wybrano trzy elementy znaku graficznego: kształt, barwę znaku oraz rodzaj czcionki, jaką zapisany jest mikrotoponim. Uwzględniono także szyldy zewnętrzne przedsiębiorstw oraz funkcjonowanie znaku graficznego firmy na stronie internetowej.

Znaki graficzne przedsiębiorstw zostały podzielone na cztery grupy (według klasyfikacji zaproponowanej przez E. Stopę-Pielesz): symbole, znaki liternicze, logo oraz znaki kombinowane [Stopa-Pielesz 2002: 20 i n.].

Symbol to forma znaku firmowego, która nie zawiera nazwy przedsiębiorstwa, tym samym może początkowo utrudniać jego identyfikację, np.: Klinika leczenia niepłodności GAMETA (www.gameta.pl) ${ }^{8}$.

Jak zauważa Stopa-Pielesz, wadą zastosowania tego rodzaju znaku są wysokie koszty promocji, która ma na celu (podobnie jak w przypadku znaku literniczego) utrwalić symbol w pamięci odbiorców, uświadomić jego znaczenie oraz wyeliminować możliwość pomylenia $\mathrm{z}$ innymi symbolami. W zebranym materiale odnotowano tylko jeden przykład symbolu. Ma on prostą formę i wywołuje pożądane przez nadawców skojarzenia $\mathrm{z}$ takimi wartościami, jak: rodzicielstwo, troska, opieka.

Znak literniczy to kompozycja liter lub cyfr, funkcjonująca często jako skrót długiej nazwy przedsiębiorstwa [por. Stopa-Pielesz 2002: 22], np.: VIP MEDICA (www.vipmedica.pl), MED-MAR (www.med-mar.pl).

Zaletą znaku literniczego jest jego zwięzłość, wadą natomiast (podobnie jak w przypadku symbolu) są wysokie koszty związane z wypromowaniem znaku, utrwaleniem go w świadomości konsumentów, by nie był mylony ze znakiem literniczym innej firmy. Dlatego też, jak pokazują przywołane przykłady, obok znaków literniczych w znaku graficznym firmy umieszczana jest jej pełna nazwa, co ułatwia identyfikację. Całość dopiero wtedy wydaje się przejrzysta i czytelna.

W zebranym materiale do najczęściej stosowanych znaków graficznych przedsiębiorstw należą: logo oraz znaki kombinowane.

Logo jest graficznym opracowaniem nazwy firmy (lub produktu), np.: IKS-DENT (www.iksdent.pl), Kavo (www.kavo.pl), BEJA-MED (www.beja-med. pl), Adverti (www.adverti.pl), FAMED Łódź (www.famed.organika.com.pl), MEDORT (www.medort.com.pl).

Główny elementem logo jest nazwa danej firmy, dzięki czemu odbiorca bez trudu może zidentyfikować przedsiębiorstwo. Oprócz firmonimu umieszcza się niekiedy także część deskrypcyjną nazwy, co ułatwia identyfikację branży, w jakiej działa dana placówka.

${ }^{8}$ Wybrane znaki graficzne pochodzą ze stron internetowych poszczególnych firm. Ze względu na to, iż nie została uzyskana zgoda właścicieli wszystkich znaków graficznych, w pracy umieszczone zostały jedynie adresy stron internetowych, na których widnieją omawiane znaki. 
Znaki kombinowane stanowią połączenie symbolu z nazwą firmy, co sprawia, że odbiorca identyfikuje zarówno dane przedsiębiorstwo, jak i branżę, w której ono działa, np.: Almed (www.almednzoz.pl), dr Lik Clinic (www.drlikclinic.pl), V!GO (www.vigo-ortho.pl), Mediso Polska (www.mediso.pl), Mobilex (www.mobilex. pl), Wiedent (www.wiedent.com.pl), REMEDIUM (www.nzozremedium.pl).

Znaki kombinowane mogą zawierać część opisowa, wskazującą na specjalność placówki, np. Almed USŁUGI MEDYCZNE, dr Lik Clinic NIEPUBLICZNY ZAKŁAD OPIEKI ZDROWOTNEJ, lub symbol, którego wartość znaczeniowa pozostaje w ścisłym związku z działalnością firmy, np.: Mobilex - symbol wózka inwalidzkiego; Wiedent - wiewiórka, $d r$ Lik Clinic - symbol jedności i harmonii. Znaczenie symbolu nie zawsze jest jednak wyraziste i nie zawsze nawiązuje do działalności placówki (por. Mediso Polska - umieszczony w znaku symbol przypominający globus może sugerować szeroki zasięg działań firmy).

Interesującym przykładem znaku graficznego jest znak zagranicznego koncernu ortopedycznego $V ! G O$. Elementem nazwy, wskazującym na działalność może być angielski człon go; zarówno firmonim, jak i zaprojektowany symbol (przypominający bumerang) nie kojarzą się w sposób oczywisty z branżą ortopedyczną. Znak graficzny jest jednak poszerzony o slogan reklamowy, który bezpośrednio informuje klienta o specjalizacji firmy: helping people move on, a także wyraża misję i filozofię przedsiębiorstwa.

Oryginalny, niepowtarzalny znak firmowy zwraca uwagę odbiorców, ale nadmiar elementów znaku graficznego może powodować zakłócenia w komunikacji między firmą a klientem, warto więc położyć nacisk na przejrzystość i czytelność znaku. Zalecenia dotyczące tworzenia nazw firm są istotne także w odniesieniu do znaków graficznych. Należą do nich m.in. rozpoznawalność znaku, łatwość zapamiętywania, wywoływanie pozytywnych skojarzeń, atrakcyjność, czytelność, przejrzystość pod względem technicznym czy odpowiednio dobrana kolorystyka. Elementy te są niezwykle ważne w procesie kreowania wizerunku firmy [por. Stopa-Pielesz 2002: 33].

Przy tworzeniu znaku graficznego istotne jest również określenie tła, na jakim będzie on prezentowany. Stopa-Pielesz posługuje się terminem pole ochronne. Może ono przybierać różne kształty. Do najczęściej stosowanych w branży medycznej zaliczyć należy prostokąt (por. Salve, Wiedent, czy HA-DENT) i kwadrat (por. Almed, GAMETA, REMEDIUM). W znakach firm: Almed oraz REME$D I U M$ posłużono się symbolem krzyża, co stanowi bezpośrednie nawiązanie do działalności tych placówek. Znak graficzny firmy REMEDIUM jest przykładem tego, jak słowo i obraz uzupełniają się i tworzą spójny przekaz: łacińska nazwa firmy, która można kojarzyć z tradycją, wzbogacona została prostym, także „tradycyjnym", znakiem krzyża.

Niekiedy w celu wyróżnienia znaku danej firmy twórcy nadają mu oryginalny, nieregularny, dynamiczny kształt. Na szczególną uwagę zasługują znaki takich przedsiębiorstw, jak: BEJA-MED czy $d r$ Lik Clinic. W pierwszym przykładzie 
tłem znaku jest obraz budynku, w którym mieści się siedziba placówki, a firmonim wraz z deskrypcją umieszczone są w prostokątnym polu. Znak graficzny firmy $d r$ Lik Clinic o nieregularnym kształcie okręgu, w którym umieszczony jest obraz twarzy z kolistym symbolem harmonii, stanowi pośrednie nawiązanie do usług medycznych oferowanych przez klinikę.

W materiale znalazły się też znaki bez geometrycznego ograniczenia. Do takich zaliczyć można logo firmy Kavo czy znak literniczy VIP MEDICA.

Elementem wpływającym na kształt znaków graficznych nazw firmowych jest krój pisma. W zgromadzonych znakach graficznych mikrotoponimów wykorzystano następujące rodzaje pisma: (a) czcionki klasyczne: antykwy, np. REMEDIUM; GAMETA; FRODENT; nadające znakom literowym prosty, ale elegancki kształt; (b) czcionki ozdobne, np. Mobilex; Kavo; $V ! G O^{9}$; oryginalny zapis z pewnością wyróżnia się na tle grafii innych mikrotoponimów, ale niekiedy jest nieczytelny, więc i niefunkcjonalny; (c) pismo stylizowane na odręczne, np. Adverti ${ }^{10} \mathrm{i}$ Wiedent (nazwy ponadto zostały zapisane kursywa); taki zapis także może sprawiać, że nazwa będzie mało czytelna, ale stylizacja na zapis odręczny skraca dystans między nadawcą a odbiorca, przełamuje oficjalność kontaktu.

Aby nazwa była czytelna, wyraźna i przyciagała uwagę odbiorcy, tworzące ją litery lub wybrane jej elementy (np. cząstki morfologiczne) mogą być pogrubione (por. BEJA-MED, Mobilex, MEDORT, człon dent $w$ nazwie IKS-DENT). Ponadto aby uatrakcyjnić grafię lub wyróżnić wybrany przez nadawcę element nazwy, wykorzystuje się czcionki o różnej wielkości (por. por. znaki graficzne takich firm, jak: BEJA-MED, FAMED Łódź, MEDMAKS, V!GO, VIP MEDICA, REMEDIUM). Pomysłodawca wyróżnia w ten sposób element nazwy, który jego zdaniem jest najistotniejszy. Zwykle jest to firmonim lub cząstka morfologiczna informująca o specjalizacji firmy, np. -med, -dent, rzadziej pojedyncze litery (np. pierwsza i ostatnia, por. FAMED Łódź).

Istotnym elementem nie tylko znaku graficznego firmy, ale również całościowego jej wizerunku jest kolorystyka. Kolor jako składnik znaku graficznego lub słowno-graficznego [por. Zboralski 2000: 207] może być zarejestrowany i zastrzeżony w Urzędzie Patentowym, aczkolwiek musi odróżniać się od znaków już zarejestrowanych ${ }^{11}$. Dobrze dobrana kolorystyka staje się znakiem rozpoznawczym

${ }^{9} \mathrm{~W}$ zapisie nazwy literę i zastapiono wykrzyknikiem przypominającym kształtem odwrócone $i$.

${ }^{10}$ Dla urozmaicenia zapisu nazwy Adverti zamiast kropki nad samogłoską i umieszczono piktogram słońca.

${ }^{11}$ Por. art. 5 Ustawy o zwalczaniu nieuczciwej konkurencji z dn. 16 kwietnia 1993 roku. Por. Ustawa z dnia 31 stycznia 1985 roku o znakach towarowych oraz Ustawa z dnia 30 czerwca $2000 \mathrm{r}$. o prawie własności przemysłowej. W art. 132 par. 2 jest następujący zapis: „Nie udziela się prawa ochronnego na znak towarowy: 1) identyczny do znaku towarowego zarejestrowanego lub zgłoszonego do rejestracji (o ile znak taki zostanie zarejestrowany z wcześniejszym pierwszeństwem na rzecz innej osoby dla identycznych znaków [...]; 2) identyczny lub podobny do znaku towarowego, na który udzielono prawa ochronnego lub zgłoszonego w celu uzyskania prawa ochronnego (o ile na znak taki zostanie udzielone prawo ochronne) z wcześniejszym pierwszeństwem na rzecz innej osoby dla 
danej firmy, na stałe wpisuje się w świadomość konsumentów (por. przykłady takich znanych marek, jak: Coca-Cola - kolor czerwony, Pepsi - kolor niebieski, czerwony i biały czy Tesco - czerwony i niebieski).

Kolory oddziałują na człowieka, wpływają na jego samopoczucie i wywołują określone emocje. Mają też swoją symbolikę uwarunkowaną kulturowo. Jak podkreśla E. Stopa-Pielesz „barwy ciemne, stonowane, nasycone, kojarzą się z powagą, wzbudzają zaufanie [...]. Barwy jasne, żywe odwołują się do witalności, nowoczesności, mogą służyć zaakcentowaniu takich cech wizerunku, jak: innowacyjność, otwartość, elastyczność" [Stopa-Pielesz 2002: 49].

W branży medycznej najchętniej wykorzystywane są dwa kolory: odcienie koloru niebieskiego i zielonego.

Kolor niebieski dominuje w wizerunku takich firm, jak: CENTRUM BADAŃ WETERYNARYJNYCH VETCOMPLEX, GAMETA (pastelowy, stonowany odcień niebieskiego przeważa także na stronie internetowej firmy), Mobilex (znak graficzny firmy umieszczony jest na granatowym tle na stronie internetowej), $H A$ -DENT, MEDMAKS (nazwa firmy przybrała kolor granatowy, co sprawia, że wyróżnia się na jasnym tle strony internetowej), $V ! G O$ (zarówno treść, jak i symbol w znaku kombinowanym umieszczone są na jasnoniebieskim tle), Kavo (firmonim oraz strona internetowa utrzymane są w spokojnej tonacji niebieskiej). Kolor niebieski można łączyć z takimi istotnymi dla właściwego funkcjonowania firm medycznych wartościami, jak bezpieczeństwo, spokój, opieka.

Kolor zielony, na trwale już związany z branżą medyczną jako kolor uniformów personelu placówek medycznych, odnaleźć można w systemach wizualnych następujących przedsiębiorstw: Almed, Mediso Polska (przeważa stonowany odcień zieleni), FAMED Łódź (intensywny zielony, w nazwie połączony z czernią; na stronie internetowej firmy natomiast obok zieleni występuje kolor pomarańczowy), IKS-DENT (człon odantroponimiczny zaznaczony jest na zielono, zaś cząstka morfologiczna -dent na czarno).

Rzadziej występują takie kolory jak czerwony (który jest widoczny i przyciagga uwagę odbiorców, a także symbolizuje ekstrawagancję, nowoczesność, por. $B E J A-M E D$, RedMed - nazwa koloru zawarta jest w nazwie), srebrny (z którym łączą się takie wartości, jak elegancja, elitarność czy prestiż, por. VIP MEDICA), szary, por. Adverti ${ }^{12}$, żółty (por. element symbolu placówki $d r$ Lik Clinic).

towarów identycznych lub podobnych, jeżeli istnieje ryzyko wprowadzenia odbiorców w błąd, które obejmuje w szczególności ryzyko skojarzenia znaku ze znakiem wcześniejszym; 3) identyczny lub podobny do renomowanego znaku towarowego zarejestrowanego lub zgłoszonego z wcześniejszym pierwszeństwem [...], jeżeli mogłoby to przynieść zgłaszającemu nienależną korzyść lub być szkodliwe dla odróżniającego charakteru bądź renomy znaku wcześniejszego" [ Dz. U. 2001, nr 49, poz. 508].

${ }^{12}$ Zarówno nazwa, jak i strona internetowa firmy został utrzymane w odcieniu szarości. W celu ożywienia i urozmaicenia nazwy kropce w literze i nadano kształt słońca. Jej żółta barwa wyróżnia się w szarej nazwie. Szarość jest rzadko stosowaną barwą ze względu na to, iż jest słabo widoczna, zwłaszcza na białym tle, np. na drukach firmowych, wizytówkach itp. 
Zastosowanie intensywnych kolorów w znaku graficznym (por. IKS-DENT) lub użycie kolorów skontrastowanych (por. Mobilex) ma uzasadnienie praktyczne: wyróżnia się w ten sposób nazwę lub niektóre jej elementy, np. cząstki morfologiczne, i tym samym zwraca uwagę odbiorców na znak. Intensywne, ostre, wyraziste kolory są także łączone z nowoczesnością i dynamika, natomiast kolory stonowane z tradycją, klasyką, statycznością i statecznością. Zwykle w znakach graficznych stosuje się dwa kolory, znacznie rzadziej trzy lub więcej. To pokazuje, że twórcy w tym względzie dążą do prostoty. Nadmiar kolorów może zakłócać odbiór znaku. Nie bez znaczenia pozostają także względy techniczne. Łatwiej jest w praktyce posługiwać się znakiem, w którym zastosowano wąską paletę barw, niż znakiem, w którym użyto kilku kolorów. Przy tworzeniu kompozycji kolorystycznej znaku istotne wydaje się również to, by nie stosować zbliżonych do siebie odcieni tej samej barwy. O ile na stronie internetowej taki znak może doskonale funkcjonować, o tyle trudność sprawi zachowanie kolorystyki na drukowanych firmowych dokumentach.

W zebranym materiale do najmniej widocznych znaków graficznych zaliczyć można logo firmy MEDORT, na które składa się nazwa przedsiębiorstwa zapisana kursywą białymi, pogrubionymi literami z szarym konturem. Całość ożywia pomarańczowy element łączący litery $d$ oraz $o$. Na stronie internetowej logo firmy, by było w pełni widoczne, zostało umieszczone na granatowym tle. Znak graficzny firmy został więc de facto zmieniony.

Ostatnim elementem corporate design, który został poddany analizie, jest reklama zewnętrzna wybranych firm. Do najczęściej stosowanych zalicza się tradycyjne szyldy zewnętrze, które stanowią jeden $\mathrm{z}$ wielu rodzajów reklamy przedsiębiorstwa. Zwykle umieszczone są w widocznym miejscu na budynkach, w których znajdują się siedziby poszczególnych firm. Wśród zebranych przykładów przeważają szyldy jednostronne, w których centralne miejsce zajmuje nazwa firmy. Oprócz znaku graficznego firmy (logo, znaku kombinowanego czy literniczego) szyldy często zawierają dokładne dane adresowe placówki, a także adresy stron internetowych czy poczty elektronicznej. Kolorystyka szyldu i znaku graficznego prezentowanego na stronie internetowej powinna być identyczna (por. $V ! G O$ - szyld zawiera także adres strony internetowej i pełną nazwę firmy oddaną za pomocą liter przestrzennych czy szyld placówki $d r$ Lik Clinic, w którym zachowano ciepłe odcienie barwy żółtej i pomarańczowej), co świadczy o przemyślanym i spójnym systemie identyfikacji wizualnej danej firmy. Zmiana kolorystyki szyldu może wynikać ze względów technicznych, por. szyld firmy VIP MEDICA, w którym zachowanie srebrnych liter firmonimu na białym tle spowodowałoby słabą widoczność znaku, na szyldzie więc biały znak literniczy umieszczono na czarnym tle. Świadczy to jednak o tym, że na etapie tworzenia znaku nie przewidziano ograniczeń technicznych wynikających z zastosowania wybranej kolorystyki.

Obok szyldów jednostronnych w reklamie zewnętrznej wykorzystywane są kasetony, czyli powierzchnie reklamowe, które mogą być mocowane prostopadle 
bądź równolegle do płaszczyzny elewacji budynku. W celach reklamowych kaseton zastosowała m.in. niepubliczna placówka medyczna REMEDIUM. Umieszczony wysoko, prostopadle do powierzchni elewacji jest widoczny z daleka dzięki temu, że zmianie uległa kolorystka znaku: na białym tle umieszczono niebieskie litery składające się na nazwę zakładu. Innym sposobem na zareklamowanie firmy, który ułatwia również jej lokalizację, jest umieszczanie na budynkach liter przestrzennych tworzących nazwę placówki. Taki rodzaj reklamy zastosowano w przypadku firmy MEDORT, ale - również ze względów technicznych - zmieniona została kolorystyka liter: z białej na granatową, dzięki czemu litery są dobrze widoczne.

W zebranym materiale przeważają znaki graficzne, których dominującym składnikiem jest nazwa firmy, a obraz stanowi jej dopełnienie i podkreśla elementy strukturalno-semantyczne firmonimu. Niekiedy nazwa wywołuje pośrednie asocjacje u odbiorców, a dopiero odpowiednio dobrany znak graficzny upewnia odbiorcę co do specjalizacji obiektu (np. Mobilex) i nadaje całości sens. Można także wskazać przykłady znaków, w których na znaczenie całości składa się w równym stopniu słowo i obraz (por. GAMETA). Rzadziej oba komponenty znaku (słowo i obraz) nie są ze sobą bezpośrednio powiązane (por. Mediso Polska) [Piekot 2007: 444 i n.].

Na podstawie wybranych przykładów funkcjonowania mikrotoponimu w systemie identyfikacji wizualnej łódzkich firm medycznych można zauważyć, iż nie jest rzeczą łatwą ani stworzenie dobrej nazwy przedsiębiorstwa, ani dobrze przemyślanej kompozycji wizualnej z nazwą firmy w centralnym miejscu, która przyczyniałaby się do kreowania spójnego wizerunku przedsiębiorstwa. Dotyczy to w szczególności małych, lokalnych firm, które rzadko mają profesjonalnie przygotowany system identyfikacji wizualnej. Zebrane przykłady pokazały, że niejednokrotnie zmiana nośnika nazwy firmy powoduje konieczność zmiany znaku firmowego, a to nie działa na korzyść stabilizacji wizerunkowej przedsiębiorstwa. Połączenie elementów strukturalno-semantycznych mikrotoponimu z wizualnymi właściwościami znaku graficznego firmy powinno tworzyć spójną i względnie trwałą kompozycję oddziałującą perswazyjnie na klienta.

\section{Bibliografia}

Breza Edward, 1998, Nazwy obiektów i instytucji zwiqzanych z nowoczesna cywilizacja (chrematonimy), [w:] Ewa Rzetelska-Feleszko (red.), Polskie nazwy własne. Encyklopedia, WarszawaKraków, 348.

Fleischer Michael, 2003, Corporate identity i public relations, Wrocław.

Gałkowski Artur, 2008, Chrematonimy w funkcji kulturowo-użytkowej. Onomastyczne studium porównawcze na materiale polskim, włoskim, francuskim, Łódź.

Handke Kwiryna, 1998, Nazewnictwo miejskie, [w:] Ewa Rzetelska-Feleszko (red.), Polskie nazwy własne. Encyklopedia, Warszawa-Kraków, 283. 
Kucała Marian, Urbańczyk Stanisław, 1999, Encyklopedia języka polskiego, Kraków.

Łobodzińska Romana, 2000, Nazwy sklepów jako przykład produktywnych wspótcześnie nazw własnych, „Rozprawy Komisji Językowej WTN”, t. XXVI, 71-77.

Nikodemska-Wołowik Anna Maria, Górski Tadeusz II Piotr, Wołowik Mirosław, 2004, Nie tylko logotyp. Wyróżnienie i przynależność w biznesie, Bydgoszcz.

Piekot Tomasz, 2007, Perswazyjność przekazów werbalno-wizualnych, Mechanizmy perswazji i manipulacji, red. Grażyna Habrajska, Anna Obrębska Łódź, 439-448.

Ragin-Skorecka Katarzyna, 2010, Corporate Identity, Poznań.

Rzetelska-Feleszko Ewa (red.), 1998, Polskie nazwy własne. Encyklopedia, Warszawa-Kraków.

Stopa-Pielesz Ewa, 2002, Corporate design, czyli jak sprawić, by estetyka pracowała na sukces firmy, Kraków.

Zboralski Marek, 2000, Nazwy firm i produktów, Warszawa.

\title{
Źródla internetowe
}

www.krs-online.com.pl

www.sjp.pwn.pl/szukaj/mikrotoponim

\author{
Marta Ułańska
}

\section{Microtoponyms in the corporate design of the selected local medical companies from Lodz}

\author{
(Summary)
}

The purpose of this research/text is the analysis of the selected items of corporate design on the examples of companies of Lodz. The main problem is the microtoponym-name - its functioning in the system as well as a connection of structural and semantic elements of the business name with the visualization of the company. Gathered material includes some about 100 names of companies specializing in the medical industry. The corporate design is one of the most important components influencing the process of creating the corporate image. The business name, as a linguistic sign, requires the visual setting. There were chosen three elements of the logo for analysis: the shape, the color of the sign and the type of the font with which a microtoponym-name is written. There were also considered two things: outside signs of enterprises and the way the trademark functions on the website. Moreover, the connection of structural and semantic elements with the visual transmission was observed.

Słowa klucze: mikrotoponim, system identyfikacji wizualnej, znak graficzny.

Keywords: microtoponym, corporate design, graphic sign. 